\title{
CRANIAL APPLICATION OF A PULSED DIRECT ELECTRIC CURRENT AND RANDOM SOUND IN | DOGS
}

\author{
J W R MClntyre, MD, W: J Confield, B sc, J Voloshin, B sC,
} AND O S JKENNA

Since THE PUBlication of the work of Anan'ev, ${ }^{1}$ interest has been taken in direct electrical current with a superimposed square wave for anaesthetic purposes This report describes some of the effects of a pulsed direct current applied to dogs, and the use of random noise

The electrical apparatus-a D C generator-was designed and bult by one of us (W J C ) It is a power amplifier capable of 100 volts into $400 \mathrm{ohms}$, driven from the internal pulse generator, D C voltage source, the external input, or a combination of these (F1gure 1) The pulse generator has adjustable repetition rate and pulse width, all three inputs being amplitude-adjustable pror to the

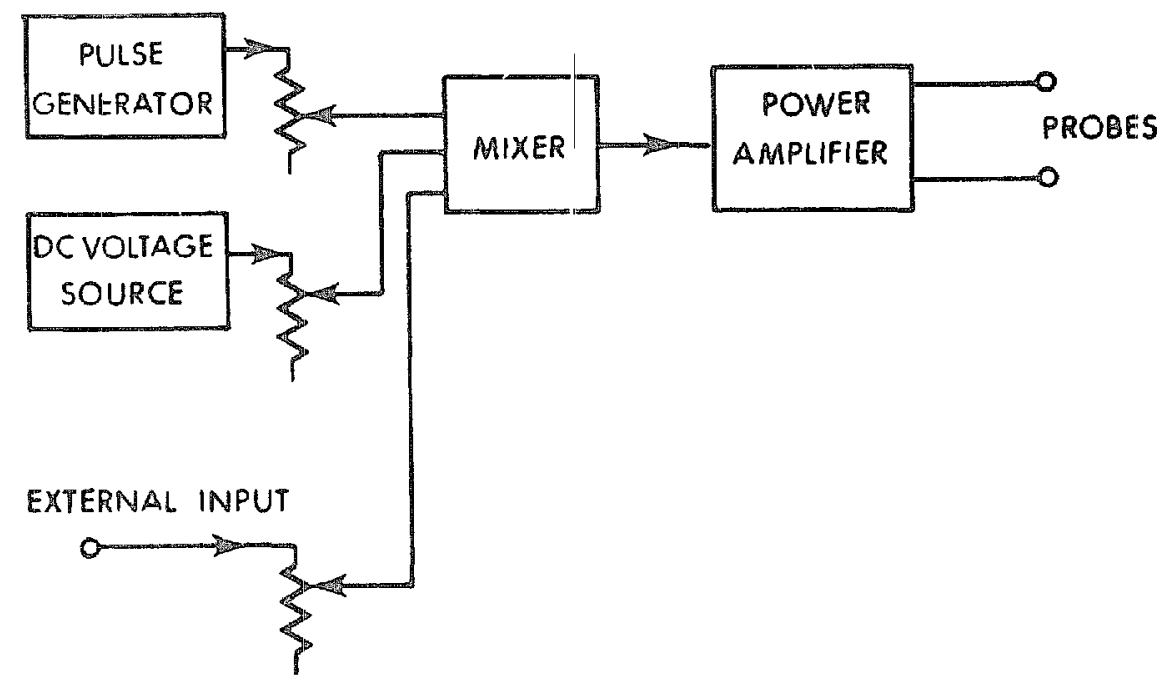

Figure 1 Direct-current generator

mixer The mixer drives the power amplifier as shown For the final power stage a solid-state amplifier was designed with feedback arranged to give a constant current output over a constant voltage. Small changes in resistance of the dog and electrode contacts would then not effect the current Care was exeicised to see that the pulse generator-a free-running multivibrator with pulse shapinggave a "clean" square pulse It was possible to set on a $\mathrm{DC}$ level and add to it a pulse of chosen width and repetition 1 ate and have the output $\mathrm{DC}$ level uneffected by the addition of the pulses

The random-noise generator used for some phases of the experiment was the General Radio Type 1390-B This generator is designed to deliver the same level of noise at any frequency in the range being used $A$ narrow band is used for measurement

Palladium electrodes $2 \mathrm{~cm}$ in drameter and a conducting gel were maintained

'Departments of Pharmacology and Anaesthesia, University of Alberta, Edmonton, Alta

Can Anaes Soc J, vol 12, no 2, March, 1985 
in position by two alternative methods A tong type holder as suggested by Smith$^{2}$ allowed current to pass between the postenor hard palate (anode placement) and the posterior part of the vertex (cathode placement) A second method allowed firm application of the anode in the mid-line below the eyes, and of the cathode in the same position as before Each palladium conductor was set in a plastic disk mounted on a rod, the whole being movable up and down a closefitting plastic sleeve, but allowing the conductor to project beyond the end of the sleeve The rod could be immobilized at any desired level inside the sleeve-one end of which was threaded-by means of a threaded disk fixed to the rod The plastic sleeves, suitably positioned, were incorporated in a plaster cast made for the head of each dog The ears and eyes were not covered The cast was then bivalved honzontally at the level of the angles of the mouth This permitted easy application of the cast, adhesive tape being used to keep the segments firmly in apposition

Six mongrel dogs 14-25 kg in weight, selected for thelir similarity in head shape, were used, and attempts were made to assess the elfects of different current applications in each dog, using the two alternative electrode placements Before the casts were made the heads were shaved Pror to each experment thopentone $15 \mathrm{mg} / \mathrm{kg}$ was administered intravenously followed by endotracheal intubation, except on six occasions when a combination of dihydrobenzpyridol $02-10 \mathrm{mg} / \mathrm{kg}$ and fentanyl $0004-002 \mathrm{mg} / \mathrm{kg}$ was substituted for thiopentone Analgesia wals assessed by the muscular and respuratory response to the application of a haemostat to the distal part of the tanl, dorsum of paws, and abdominal wall The electric current was not applied until signs of spontaneous arousal were present Blood piessures were measured by arterial cannulization and temperature by rectal thermometer

The durect current was introduced first, increasing at 5 ma a minute until a maximum of $20 \mathrm{ma}$ was reached The first $5 \mathrm{ma}$ produced no visible alteration in respiration or muscle tone, but as the current increased, slight movements of the head and limbs occurred The use of a high rate of current flow did not appear to be advantageous and in the majonty of experrments the direct current was limited to $5 \mathrm{ma}$

A valiety of pulsed currents were used, each mtroduced smoothly at 5 or 10 ma / minute, and the results are as follows

$100 \mathrm{cps} 1 \mathrm{~ms}$-to a maximum of $135 \mathrm{ma}$ At 5 ma the dog remained motionless, would get up if the current was turned off, and could be aroused by a loud noise Respiration was slow, regular, with adequate volume, and analgesia was absent When the current was increased muscle tone increased and tremors occurred, first in the forequarters and spreading to the rest of the body These signs persisted whether the curnent was added at 5 or 10 ma per minute, and as it increased respiration became more embarrassed by muscle spasm and defaecation sometumes took place

$100 \mathrm{cps} 2 \mathrm{~ms}$-to maximum of $37 \mathrm{ma}$ Alteration in rhuscle tone and respiratory changes were infrequent, but though the anmall was motionless, relaxed, and rousable only by a very loud noise, response to painful stimuln was invariably present regardless of the electrode placement 
$200 \mathrm{cps} .2 \mathrm{~ms}$ - to maximum of $50 \mathrm{ma}$ Muscle tremors occurred and no analgesia was achieved

$200 \mathrm{cpss} 1 \mathrm{~ms}-10 \mathrm{maximum}$ of $42 \mathrm{ma}$ Results were similar to those obtanned with $200 \mathrm{cps}$ and $2 \mathrm{~ms}$

$200 \mathrm{cps} .2 \mathrm{~ms}$-followed by $100 \mathrm{cps} 1 \mathrm{~ms}$ Pulsed direct current was increased to approximately $35 \mathrm{ma}$ over a period of one minute and at this point the frequency was reduced to $100 \mathrm{cps}$ and the current increased to $50 \mathrm{ma}$ The pulse width was then reduced to $1 \mathrm{~ms}$ and the current increased to $100 \mathrm{ma}$ Muscle spasm, respiratory stimulation ensued, with absence of analgesia

Rectal temperatures invariably minceased up to $25^{\circ} \mathrm{C}$ above the resting level This could be controlled with the use of ice packs or paralysis with succinylcholne and artificial ventilation Application of electric current to the animals resulted in a substantial increase in systolic and diastolic pressures, particularly when signs of muscular activity were present This hypertension also occurred after paralysis with succinylcholine and artificial ventilation A gradual return to almost normal levels occurred, but any subsequent alterations in current flow produced further increases in blood pressure A comparuson was made between the tong and cast technique of electrode placement on sis. different dogs with each of the electrical currents used Similar results were obtained in both groups

The intravenous administration of fentanyl and dihydrobenzpyndol sedated the animals but intubation was technically difficult Currents of $100 \mathrm{cps} 1 \mathrm{~ms}$ or 100 c p s $2 \mathrm{~ms}$ were applied through cast electrodes, but a response to painful stumuli was invariably present

Random-nouse In seven experuments random noise was added to the peaks and troughs of the pulsed wave apphed to the animal through the cast electrodes Noise in the range of $20 \mathrm{kc}$ or $500 \mathrm{kc}$ was used, with peak excursions of $33 \mathrm{ma}$, and combined with a pulsed current of $100 \mathrm{cps} 2 \mathrm{~ms}$, or $200 \mathrm{cps} 1 \mathrm{~ms}$ Whenever the random noise was begun the anmal would struggle slightly, the eyes opened, and the eyeballs oscillated slowly A quiescent state did not returm and analgesia could not be demonstrated The application of random noise alone through cast electrodes produced a quilescent state from which the animal could be aroused by a loud noise Respuration at this tume was of adequate volume and unembarrassed by muscle spasm The limbs, were relaxed Analgesia was absent Increase of current beyond 25 ma invariably produced the muscular complications associated with previous current patterns

\section{Discussion}

In a number of experuments there were indications of at least some degree of analgesia, but on more careful observation it was concluded that muscle spasticity masked response to painful stumuli In any case analgesia failed to occur in any animal that was relaxed and breathing adequately As the electrical current could be used to mantann the dogs an a quitscent to relaxed state, it was thought that the use of an analgesic drug which could if necessary be administered preoperatively by intramuscular route might be combined with it 
MCINTYRE et al CRANIAL APPLICATION OF PULSED D C AND RANDOM SOUND 195

Fentanyl (McNell) is a morphomimetic drug and droperidol (McNell) is a drug with sedative and tranquillizing properties The drug combination was used for sedative purposes and no attempt was made to render the anmals analgesic prior to the application of electric current The fact that no satisfactory technique could be developed apphes only to these drugs in the dosage used It is possible that a sutable combined technique could be devised in the future

The application of electrical random noise, or a pulsed durect current, to an ammal already quiescent under the effects of a pulsed current or random noise, produced signs of stımulation It appears that the additional current acts as an extianeous stimulus producing arousal and that the initial quiescent state of the anumal is akin to hypnosis Possibly in some cases there could be a significant relationship between the administrator, electrical curcent, and the presence of analgesia at these current levels

Although the dogs' behaviour in the period between experiments did not apparently change, the animals were untrained and no attempts were made to assess cerebral function The work of Lilly ${ }^{3}$ and his colleagues indicates caution in the use of unidrectional curnents because of possible cortucal injury, and as a duect current up to $20 \mathrm{ma}$ appeared to have no anaesthetic value, only $5 \mathrm{ma}$ was employed in the majority of cases

It was concluded from these experiments that the rnethod of electrode placement described was satisfactory, particularly if there was a possibility of unexpected movements by the $\operatorname{dog} \mathbb{A}$ variety of electrical currents could maintain a quiescent and relaxed state, but analgesia, by the standards of assessment used, could not be produced

\section{SUMMARY}

A pulsed durect electrical current was applied to the heads of adult dogs through palladum electrodes These were located on the posterior hard palate and inion, or between the eyes and just behind the mion In the latter instance a plaster cast was used to keep the electrodes in position Prior to the current application the animals were sedated with thiopentone, or, in a few cases, with a combination of fentanyl and dropendol

Currents used were $100 \mathrm{cps} 1 \mathrm{~ms}$ to a maxımum of $125 \mathrm{ma}, 100 \mathrm{cps} 2 \mathrm{~ms}$ to a maximum of $37 \mathrm{ma}, 200 \mathrm{cps} 2 \mathrm{~ms}$ to a maximum of $50 \mathrm{ma}, 200 \mathrm{cps} 1 \mathrm{~ms}$ to a maxamum of $42 \mathrm{ma}$, random noise in the range $20 \mathrm{kc}$ or $500 \mathrm{kc}$ to a peak of $33 \mathrm{ma}$ A variety of currents produced a relaxed quiescent animal but analgesia could not be demonstrated An increase in current produced muscular spasticity

\section{$\mathbb{R}$ ÉSUMÉ}

Au moyen d'électrodes en palladium, nous avons appliqué un courant électrique durect (pulsatile) sur la tête de chrens adultes Nous avons placé ces électrodes l'une sur la partie posténeure du palais dur et l'autre sur l'mion, ou encore entre les yeus et juste en arrière de l'mion Dans cette dernère éventualnté, nous avons 
employé un plâtre pour maintenır les électrodes en place Avant d'applıquer le courant, nous avons donné une sédation aux chiens parfors nous avons utılisé du thiopentone ou, dans quelques cas, un mélange de fentanyl et de dropéridol

Nous avons employé les courants suvvants $100 \mathrm{cp} \mathrm{s}, 1 \mathrm{~ms}$ jusqu'à un maxımum de $125 \mathrm{ma}, 100 \mathrm{cps}, 2 \mathrm{~ms}$ jusqu'à un maxımum de $37 \mathrm{ma}, 200 \mathrm{cps}, 2 \mathrm{~ms}$ jusqu’à un maximum de $50 \mathrm{ma}, 200$ c p.s., 1 ms jusqu'à un maximum de 42 ma, brutt (occasionnel) de l'ordre de $20 \mathrm{kc}$ à un maximum de $33 \mathrm{ma}$.

Une variété de courants ont produit chez l'animal une détente et un repos, mais nous n'avons pas pu démontrer d'analgésie Une augmentatıon du courant a provoqué des spasmes muscularres

\section{REFERENCES}

1 Anan'ev, M G, Golubeva, I W, Gurqva, E V, Kashchevskaia, L A , Levitskaia, L A , \& KHudyu, Yu B Preliminary Data on Experimental Electronarcosis Induced with Apparatus of Scientific Research Institute of Experimental Surgical Apparatus and Instruments Eksp Khır 43 (1957) translated in Anesthesiology 21215 (1960)

2 SMrth, R H \& Cullen, S C Electronarcosis by Combination of Direct and Alternating Current 3 Electrodes and Electrode Holders Anesthesiology 23682 (1962)

3 LILXY, J C, Austin, G M, \& Chambers, W W Threshold Movenents Produced by Excitation of Cerebral Cortex and Efferent Fibers with Some Parametric Regions of Rectangular Current Pulses (Cats and Monkeys) J Neurophysiol 15319 (1952) 